経カテーテル的動脈塞栓術により門脈内腫瘍栓が 完全壊死した肝細胞癌の 1 切除例

\begin{tabular}{lrrrrrr} 
& \multicolumn{8}{c}{ 名古屋大学医学部第 1 外科 } \\
近藤 & 哲 & 二村 & 雄次 & 早川 直和 & 神谷 & 順一 \\
所 & 昌彦 & 道家 & 充 & 塩野谷恵彦 & & \\
& & \multicolumn{5}{c}{ 山下病院 } \\
& 䯩 & 勝義 & 清水 & 信明 & 住田 & 啓
\end{tabular}

\title{
COMPLETE NECROSIS OF TUMOR EMBOLUS WITHIN THE PORTAL VEIN CAUSED BY TRANSCATHETER ARTERIAL EMBOLIZATION FOR HEPATOCELLULAR CARCINOMA, REPORT OF A RESECTED CASE

\author{
Satoshi KONDO, Yuji NIMURA, Naokazu HAYAKAWA, \\ Junichi KAMIYA, Masahiko TOKORO, Mituru DOKE \\ and Shigehiko SHIONOYA
}

1st Department of Surgery, Nagoya University School of Medicine

Katsuyoshi KOH, Nobuaki SHIMIZU and Kei SUMIDA

Yamashita Hospital

索引用語：肝細胞癌, 肝細胞癌門脈内腫瘍栓, リピオドール併用 $\mathrm{TAE}$

はじめに

一般に, 経カテーテル的動脈塞栓術 (TAE) は, 主 腫瘍に対しては広範な壊死をもたらしても, 門脈内腫 瘍栓や肝内転移巣には効果が小さい場合が多い。われ われは肝右葉後上区域 $\left(\mathrm{S}_{7}\right)$ に肝内転移を伴う肝右葉 前下・後下区域 $\left(\mathrm{S}_{5} \cdot{ }_{6}\right)$ の肝細胞癌 $(\mathrm{HCC})$ で, 門脈 前下枝から前枝本幹へ腫瘍栓が発育した症例にりピオ ドール (LPD)・マイトマイシンC (MMC) 併用 TAE 後肝切除を行い, 門脈内腫煬栓が100\%壊死に拈ちいっ たことを確認できたので報告する。

症例

40歳, 男性.

主訴: 右上腹部痛.

既往歷, 家族歷：特記事項なし。

現病歴：1986年 5 月 28 日右上腹部痛があり山下病院 を受診した。なお， 7 カ月前の検診で肝機能異常を指 摘されている。

現症：右肋弓下に肝を 2 横指硬く触知した。

$<1987$ 年11月18日受理 >別刷請求先: 近藤 每

干466 名古屋市昭和区鶴舞町65 名古屋大学医学部

第 1 外科
一般検查: WBC $8,300 / \mathrm{mm}^{3}, \mathrm{RBC} 595 \times 10^{4} / \mathrm{mm}^{3}$, $\mathrm{Hb} 18.4 \mathrm{~g} / \mathrm{dl}$, plat. $18.3 \times 10^{4} / \mathrm{mm}^{3}$. 肝機能は GOT 46KU, LDH 495WU，と軽度上昇を認めるのみで他は 正常であった. ICG 負荷試験も $\mathrm{R}_{15} 2.3 \%, \mathrm{~K}$ 値0.248 と良好であった. HBsAg(十), $\operatorname{antiHBs}(-), \mathrm{HBeAg}$ (ー)で AFPは750ng/mlであった.

超音波検查 (US) では肝実質のエコーむらが強く右 葉中心の diffuse type HCC と考えられた。

血管造影所見： $\mathrm{S}_{5} \cdot{ }_{6}$ に $13 \times 9 \mathrm{~cm}$ の辺縁不明瞭な濃 染像を認め, 他にる小結節性濃染像が右葉に多発して おり diffuse type HCC と考光られた。経動脈性門脈造 影では右前下枝が欠損しその根部に相当する部の前枝 本幹に透亮像を認め腫堭栓と診断した(図 1). 引き続 き, LPD $10 \mathrm{ml}$ と MMC $10 \mathrm{mg}$ の懸濁液を固有肝動脈 から注入し，さらに右肝動脈で MMC 10mg を浸透し たスポンゼル細片でTAEを行った。

USでTAE 後の経過を観察したところ, TAE 前お よび 4 日後には明瞭に認められた右前枝本幹内の腫堭 栓が，30日後には消失していた(図 2)。また，TAE 後 43日目に施行した plain computed tomography (CT) では, LPD の残留状態から肝内転移巣は $\mathrm{S}_{7} に 1$ 個の 
図 1 血管造影。左：動脈相早期。払張した前下枝 $A_{5}$ (矢印)，後下枝 $A_{6} に$ feeding される hypervascular tumorを認める.中：動脈相後期。大きな主腫瘍の他に多発 性の小結節状濃染像を認める(矢印)。右：門脈造影. $\mathrm{A}_{5}$ に対応する門脈枝の及が久 損しその根部に相当する部の前枝本幹に透亮像を認める（矢印）。
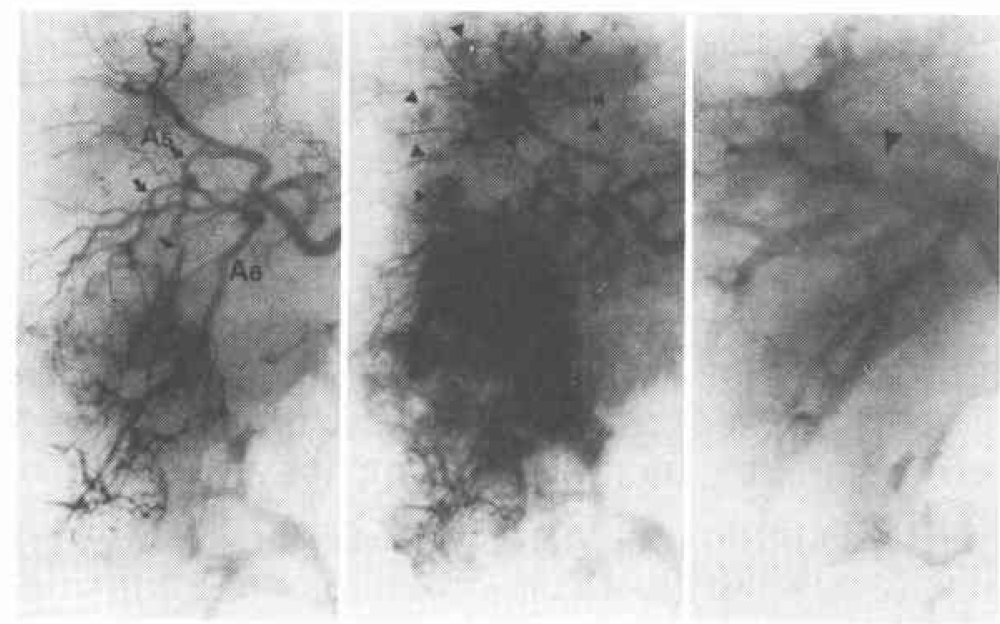

図 2 US. TAE 前（左）および 4 日後（中）には右前枝本幹内に突出する腫煬栓を認 めるが，30日後（右）には消失している。
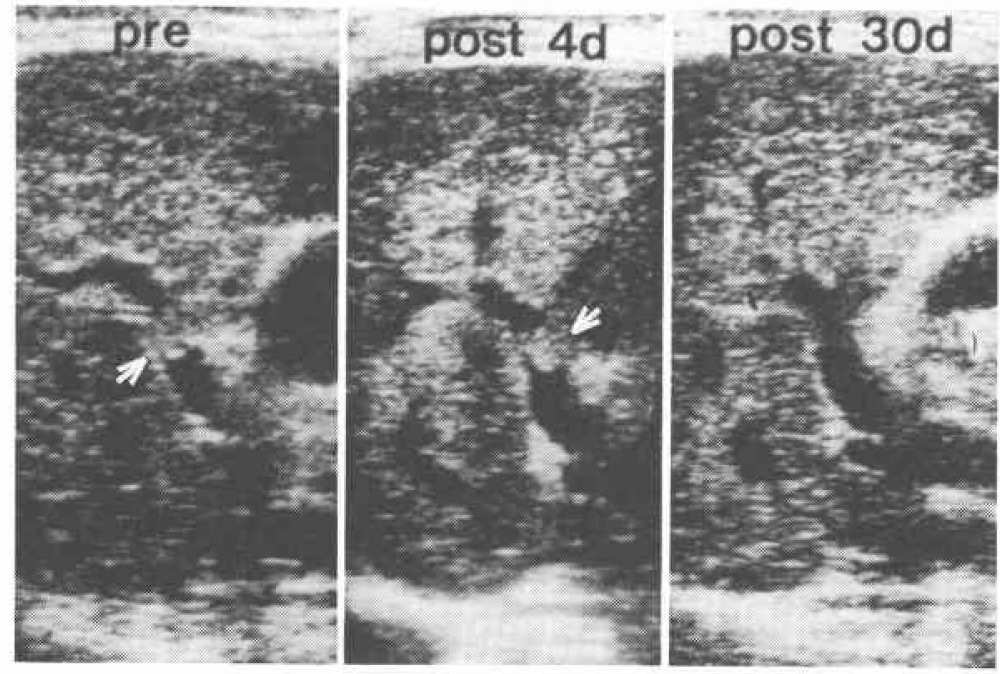

みと診断できた。 また，門脈右前下枝内腫場栓に一致

して主腫瘍近旁から頭側へのびる線状の LPD 残留が 認められた（図了）.

以上の所見から, 当初は右葉中心の diffuse type と 考党ていたが，実は $\mathrm{S}_{5} \cdot{ }_{6}$ の nodular type で $\mathrm{S}_{7}$ に 1 個 転移巣を伴い門脈内腫場栓すTAEにより縮小してい ると判断し, TAE 後50日目に桩大肝右葉切除を施行 した.
切除標本所見: $S_{5} \cdot{ }_{6}$ の主腫瘍は $7 \times 6 \times 5 \mathrm{~cm}$ で被膜 形成を認め, $\mathrm{S}_{2}, \mathrm{~N}(-), \mathrm{Vp}_{1}, \mathrm{Vv}_{0}, \mathrm{~B}_{0}, \mathrm{IM}_{2}, \mathrm{P}_{0}$, $\mathrm{M}_{0}$ で Stage III ${ }^{1}$ であった。肝内転移は $\mathrm{S}_{7}$ に 1 個認め径 $1.1 \mathrm{~cm}$ であった. 門脈を後面切開していくと, 前枝本 幹内膜面に腫瑒栓の存在していた前下枝合流部がわず かに平坦な黄色の点として認められた。この前下枝は 主腫䁑までの全長 $4 \mathrm{~cm}$ にわたり完全に閉塞して細く なって括り，黄色の索状物として認識できた（図4）。 
図 3 plain-CT (TAE後43日目). 頭側から尾側へと スライス番号を付した. $\mathrm{S}_{5} \cdot{ }_{6}$ と $\mathrm{S}_{7}$ の 2 カ所に LPD の残留を認める。ょた, slice3の主腫瘍の左に近接し た部位から頭側へのびる線状の LPD 残留が見られ る（矢印）。
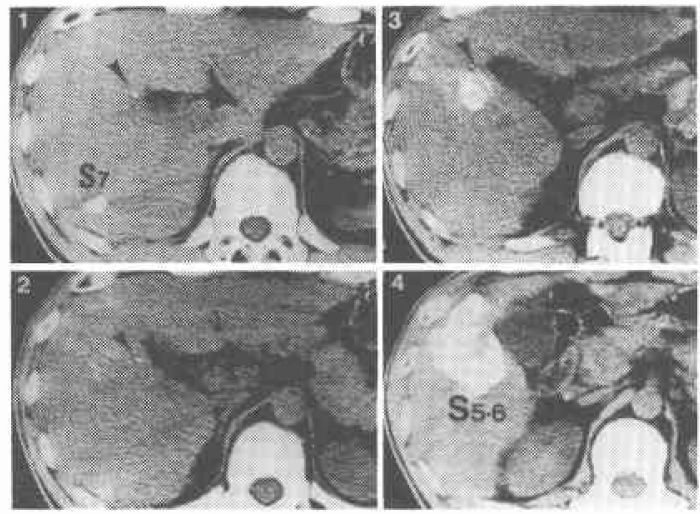

図 4 切除標本(門脈後面切開後). 門脈前下枝は前枝 本幹合流部から主腫瘍まで全長 $4 \mathrm{~cm}$ にわたり完全 に閉塞し黄色索状物と化していた（矢印）。

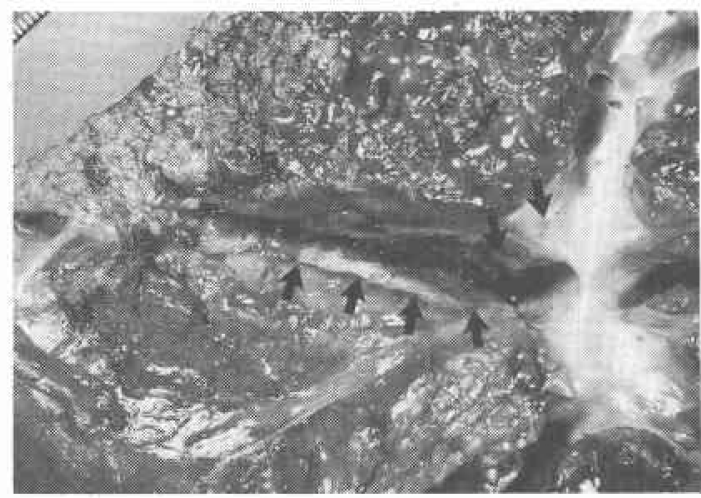

これを切開することは困難で途中で切離すると黄色の モロモロとした壊死物質が得られた。

組織学的所見：主腫瘍の被膜内部は完全に壊死して いたが，一部の被膜外浸潤部は viable で trabecular type, Edmondson III 型の所見を示していた（図 5 ). 壊死率は, 主腫瘍, 肝内転移巣ともに約 $95 \%$ であった。 門脈前下枝の内腔には, 中心部に腫瘍壊死組織が存在 しその周囲はすでに肉芽組織におきかわっており， viable な腫瘍細胞は連続切片で検討しても全く認め られなかった(図6)。なお，乙型訮硬変を合併してい た.

術後経過は良好で31日目に退院した，5力月目に孤 立性脳転移巣摘出術を受け，9力月後の現在肝肺をは
図 5 主腫瘍の組織像 $(\mathrm{HE}, \times 50)$. 左：腫煌の約 $95 \%$ は被膜内で完全壊死していた。右：一部の被膜外浸 潤部はviableであった。

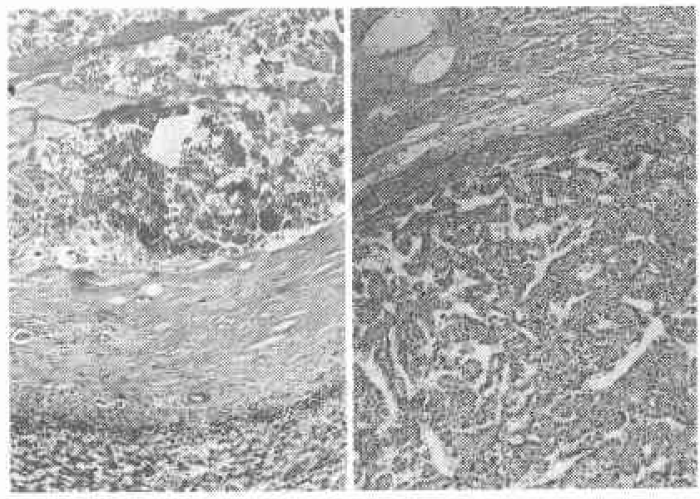

図 6 門脈前下枝の組織像 $(\mathrm{HE}, \times 25)$. 内腔は完全に 閉塞している，中心部には腫瘍壊死組織が存在する が(矢印)，その他は肉芽組織におきかわっている。 門脈枝の左に TAEにより閉塞したままの伴行動脈 孝. 7 万.

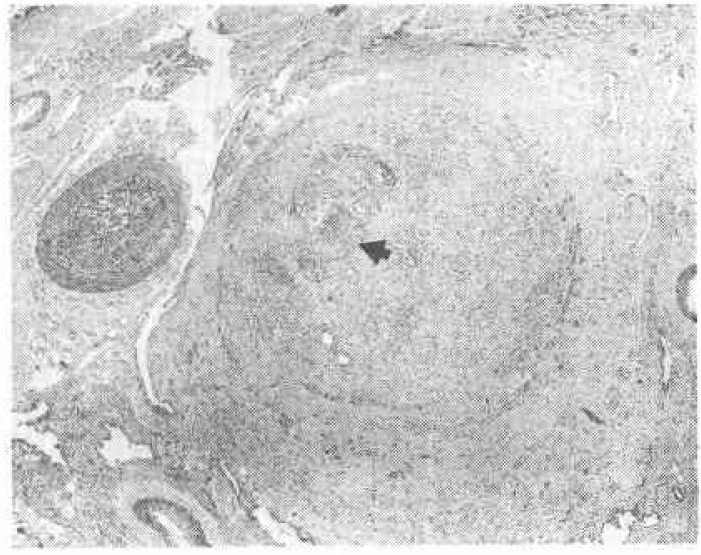

じめとして再再発はなく，元気にリハビリテーション につとめている。

\section{考察}

TAEにより HCCが広範に壊死におちいることは 事事であるが，100\%壊死は多くない。したがっで根 治”を目標とするかぎり外科的切除が必要であること はいらまでもない.しかし合併する肝硬変のために切 除範囲が制限されることが難点で, 切除断端の余裕を 十分とれないこと, 小肝内転移巣のとり残し, 癌細胞 の術中散布などが術後再発の要因と考えられている. その対応策として術前 TAEが行われてきたが2), 切除 標本の病理学的検索が行われるにつれて, 被膜部・被 
膜外浸潤, 肝内転移, 門脈内腫瘍栓には効果が小さい ことが明らかとなってきだ) 瘍に近接した肝切離縁でのとり残し, 肝切除範囲外の 小転移巣のとり残し，当然門脈内腫瘍栓からおこると 考它らる術中散布の原因となるわけで，当初の目的 は全く果されていないことになる，TAEの残存肝へ の傷害の可能性 ${ }^{67)}$ を考慮すると,この 3 病変に対する 効果がないかぎり術前 TAE は無意味どころか悪影響 を及ぼすこになってしまう。

しかしながら，最近では油性制癌剤を溶解した LPD または水溶性抗癌剂と LPDの懸濁液を動注する tar geting chemotherapy ${ }^{8}$ が開発され，その直後に従来通 りゼラチンスポンジで TAEを施行する方法（L・CTAE)が行われるよらになった. LPDの腫瘍への選択 的残留にとむなら制癌剂の徐放効果による抗腫瘍効果 の増強が期待されている9，この理論によれば，動脈・ 門脈の二重支配のために従来の TAEのみでは門脈血 流が遮断されず効果がなかった病変に対しても有効と いらことになる. 実際にLPDの残留は被膜, 肝内転移 巣, 門脈内腫瘍栓にも認められることがCTで確認さ れている(10).ささらに吉田ら ${ }^{11}$ の肝切除例の検索によれ ば1cm 以下の娘結節24個中11個に100\%壊死がみられ て寺り, 佐々木ら ${ }^{12)}$ は被膜部浸潤や門脈内腫場栓にも 有効であったと報告している.

本例では被膜外浸潤には無効であったが，転移巣に は95\%，さらに門脈右前下枝から前枝本幹へと進展す る全長約 $4 \mathrm{~cm}$ の腫痬栓は100\%壊死に括ちいってい た.この腫瘍栓に LPD が残留していることはCTで 確認されて拉り，USでも消失してゆく経過をとらえ ることができた，L・C-TAEによる效果であることは 確実といえよう，切除標本では，壊死した門脈内腫瘍 栓はなかば器質化して著しく細くなっており，注意深 い病理検索を行わないと見逃してしまう恐えもあるよ らな状態となっていた。

TAEによる門脈内腫瘍栓への効果は，厚生省班研 究2)では15例中 4 例に有効, 高崎ら ${ }^{13}$ ) は 4 例中 2 例に $80 \%$ 壊死と, 意外に有効とする報告もある.さらに L・ Cを加学れば有効率は高まることも予想され，本例の ような $100 \%$ 壊死効果も例外ではなくなる可能性すあ る.そらなれば，術中散布の防止に L・C-TAE は有意 義な手段となろう。今後症例を集積し，どのよな症 例にどのような方法を用いれば門脈内腫場栓にも有効 であるかを検討したい.

また, LPD 併用 TAE 後の CT は肝内転移巣の検出
に非常に鋭敏とされているが，本例でも血管造影での 多発する小結節性濃染像が false positiveであること を診断できた。手術適応の決定や術式の選択という点 においても非常に有用であった。

\section{おわりに}

L・C-TAEにより主腫瘍扣よび肝内転移巣は95\%， 門脈 2 次・ 3 次分枝内腫县栓は100\%壊死におちいった HCC の 1 切除例を報告した. 門脈内腫湟栓への LPD の残留がCTで確認でき，消失過程もUSでとらえる ことができた，完全壊死した門脈内腫瘍栓は注意深く 切除標本を検索しないと見逃されてしまう可能珄があ ることを強調したい。

\section{文献}

1）日本肝癌研究会編：臨床・病理原発性訮癌取扱い 規約。金原出版，東京，1983

2）原生省が九研究助成金, 計画研究, 第15班編：肝癌 に対する集学的治療一Embolizationを併用した 肝切除の検討一。肝・胆・膵 5:1195-1200，1982

3) 厚生省がん研究助成金, 計画研究, 第15班編：肝癌 に対する集学的治療一Embolizationを併用した 肝切除の険討一.内科 $52: 555-559,1983$

4）竜 崇正, 山本義一, 山本 宏活加：細小肝癌に対 する Transcatheter Arterial Embolization 併用 肝切除の意義. 肝臓 $25: 881-889,1984$

5）厇橋一裕, 酒井克治, 木下博明ほか：旰動脈塞栓療 法後肝切除施行肝細胞癌症例の臨床的ならびに病 理組織学的研究. 日外会誌 $86: 555-564,1985$

6) 羍松壮平, 滰 吉郎, 谷 友彦㳗加: 癌の集学的 治療の現況。癌の臨 $31: 1120-1128,1985$

7) 高橋 修, 宮崎勝, 营沢寛健注か：肝切除前の肝 動脈塞栓術（TAE）の安全性に関する基礎的検討. 日外会誌 $88: 74-80,1987$

8）今野俊光, 前田 浩, 横山育三ほか：原発性肝癌の 新治療法：油性リンパ管造影剂リピオドールと親 油性高分子制癌剂スマンクスの肝動脈内投与とそ の臨床成績。癌と化療 9:2005一2015，1982

9）中村仁信, 橋本 勉, 田中鐵男ほか：肝がんに対す る油性塞栓化学療法. 癌と化療 $14: 381-387$, 1987

10）徳山勝之, 神野健二, 湯本泰弘泳加：油性制癌剤之 肝動脈塞栓術の併用療法一切除小肝癌 2 例の臨床 病理学的検討一. 癌の臨 $30: 955-964,1984$

11）吉田英晃, 深井泰俊, 吉川高志ほか：肝細胞癌の制 癌剂混入 Lipiodol 併用した肝動脈塞栓術後肝 切除の意義. 日消外会誌 $19: 2358-2364,1986$

12）佐々木洋, 今岡真義, 中森正二㳗加：動脈塞栓を併 用したりピオドール・アドリアマイシン熟濁液動 注による肝細胞癌の治療一主として組織学的検討 からみた有効性について一、日癌治療会誌 20 ： $1357-1365,1985$

13）高崎 健, 小林誠一郎, 武藤晴臣ほか：門脈枝( 1 次または 2 次分枝) に腫湯塞栓を持った原発性肝 癌に対する術前肝動脈塞栓術の効果について。 日 消外会誌 $19: 1612-1617,1986$ 